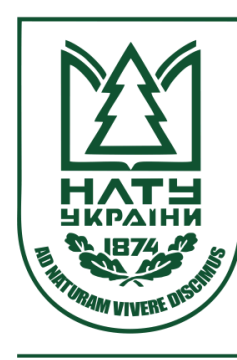

Науковий вісник НЛТУ України Scientific Bulletin of UNFU

https://nv.nltu.edu.ua

https://doi.org/10.15421/40280621

$@ \bowtie$ Correspondence author

Article received 15.06.2018 p.

Article accepted 25.06.2018 p.

S. V. Novytskyi

удк 674.038

s.v.novitsky@gmail.com

С. В. Новицький

Національний університет біоресурсів і природокористування України, м. Київ, Україна

\title{
ДЕРЕВИНОЗНАВЧІ АСПЕКТИ СУХОСТІЙНОЇ ДЕРЕВИНИ СОСНИ ЗВИЧАЙНОЇ
}

Досліджено показник водопоглинання сухостійної деревини сосни давністю усихання від одного до трьох років та деревини без ознак всихання з Київської та Житомирської областей України, зона Лісостепу. Підтверджено наявність тенденції до підвищення водопоглинальної здатності від давності всихання сухостійної деревини. Викладено результати експериментальних досліджень із впливу температури оброблення сухостійної деревини сосни звичайної (Pinus sylvestris L.) різної давності всихання з ознаками мікологічних уражень на життєздатність гіфів грибів. Проаналізовано наявні методи з визначення фізико-механічних властивостей деревини, викладені у чинних національних, гармонізованих з європейськими, та міждержавних нормативних документах. Встановлено показники щільності, межі міцності та модуля пружності за статичного згину, межі міцності за стискання вздовж волокон для пиломатеріалів із сухостійної деревин сосни звичайної, давністю всихання до одного року, порівняно з деревиною без ознак всихання. Визначено, що сухостійна деревина сосни, давністю всихання до одного року, повністю задовольняє вимоги до дерев'яних конструкцій, встановлених у ДБН В.2.6-161:2017, i можна їі використати як конструкційний матеріал. Запропоновано застосування методу евристичного моделювання для вивчення впливу деревинознавчих аспектів сухостійної деревини сосни звичайної на показники конструкційних лісоматеріалів 3 метою прогнозування можливості використання такої деревини в будівельних конструкціях.

Ключові слова: деревозабарвлювальні гриби; термічне оброблення; фізико-механічні властивості; конструкційні лісоматеріали.

Вступ. На сьогодні, внаслідок кліматичних змін, інтенсифікувались патологічні процеси у хвойних деревостанах, що призвело до їх всихання. Це стало причиною зростання, отримуваних у процесі лісозаготівель, обсягів так званої "сухостійної" деревини, основною ознакою якої $є$ ураження деревозабарвлювальними грибами. Тому виникло питання ефективного та раціонального використання такої деревини у промисловості.

Через наявності біологічних пошкоджень склалась практика використання сухостійної деревини як паливної сировини. Однак дослідження I. Н. Бєляєва (Beliaev, 2011) дають змогу припустити, що частку сухостійної деревини, посортувавши, можна використати як сировину для виробництва конструкційних елементів будівельного призначення. Окрім цього, виконані на сьогодні дослідження мінливості показників механічних властивостей сухостійної деревини залежно від терміну всихання свідчать, що міцність і якість деревини 3 деревостанів давністю всихання до 5 років під впливом абіотичних і біотичних чинників знижуються незначно. Це також дає змогу стверджувати, що таку деревину можливо використовувати для виробництва конструкційних пиломатеріалів (Larinina, 2014).

Як відомо, фізичні та механічні властивості деревини безпосередньо залежать від геокліматичних умов росту дерев, що зумовлює їх значну мінливість. Отже, дослідження цього природного матеріалу має локаль- ний характер у межах певного регіону окремої країни. Так, для визначення способів раціонального використання деревини, зокрема сухостійної, необхідно провести комплекс експериментальних досліджень з вивчення iї властивостей. Отже, метою дослідження є вивчення деревинознавчих аспектів сухостійної деревини сосни звичайної і їх впливу на показники конструкційних лісоматеріалів.

Матеріали та методи дослідження. Для виконання дослідження було відібрано зразки деревини сосни звичайної (Pinus sylvestris L.) 3 неослаблених всиханням деревостанів, без ознак мікологічних уражень (надалі здорова деревина), та з усихаючих деревостанів, давністю всихання до 1-го, 2-х та 3-х років. Відбір зразків здійснювали способом заготівлі модельних дерев 3 пробних площ (ГОСТ 16483.6-80) Київської та Житомирської областей України, зона Лісостепу. Загалом для вивчення впливу деревинознавчих аспектів сухостійної деревини сосни звичайної на показники конструкційних лісоматеріалів для прогнозування можливості використання такої деревини в будівельних конструкціях доцільно застосувати метод евристичного моделювання досліджуваного процесу, блок-схему якого наведено на рисунку.

На першому етапі виконано експериментальні дослідження 3 визначення межі водопоглинання (ГОСТ 16483.20-72) зразків здорової та сухостійної деревини

Інформація про авторів:

Новицький Сергій Володимирович, магістр, аспірант (науковий керівник: Марченко Наталія Валентинівна, канд. техн. наук, доцент, кафедра технологій та дизайну виробів з деревини). Email: s.v.novitsky@gmail.com; https://orcid.org/0000-0001-7849-0212

Цитування за ДстУ: Новицький С. В. Деревинознавчі аспекти сухостійної деревини сосни звичайної. Науковий вісник Нлту України. 2018, т. 28, № 6. С. 109-112.

Citation APA: Novytskyi, S. V. (2018). Wood technology aspects of scotch pine deadwood. Scientific Bulletin of UNFU, 28(6), $109-112$. https://doi.org/10.15421/40280621 
сосни давністю всихання до 1-го, 2-х та 3-х років. Для цього виготовляли зразки у формі прямокутної призми основою $20 \times 20$ мм та висотою вздовж волокон 10 мм. Зразки розміщували в ексикаторі під вставкою, заливали дистильованою водою так, щоб одна $з$ площин попе- речного розрізу залишалася сухою, закривали кришкою і витримували за температури $20^{ \pm 2}{ }^{\circ} \mathrm{C}$ не менше 30 діб, періодично виймаючи 3 води, осушуючи поверхню фільтрованим папером і зважуючи.

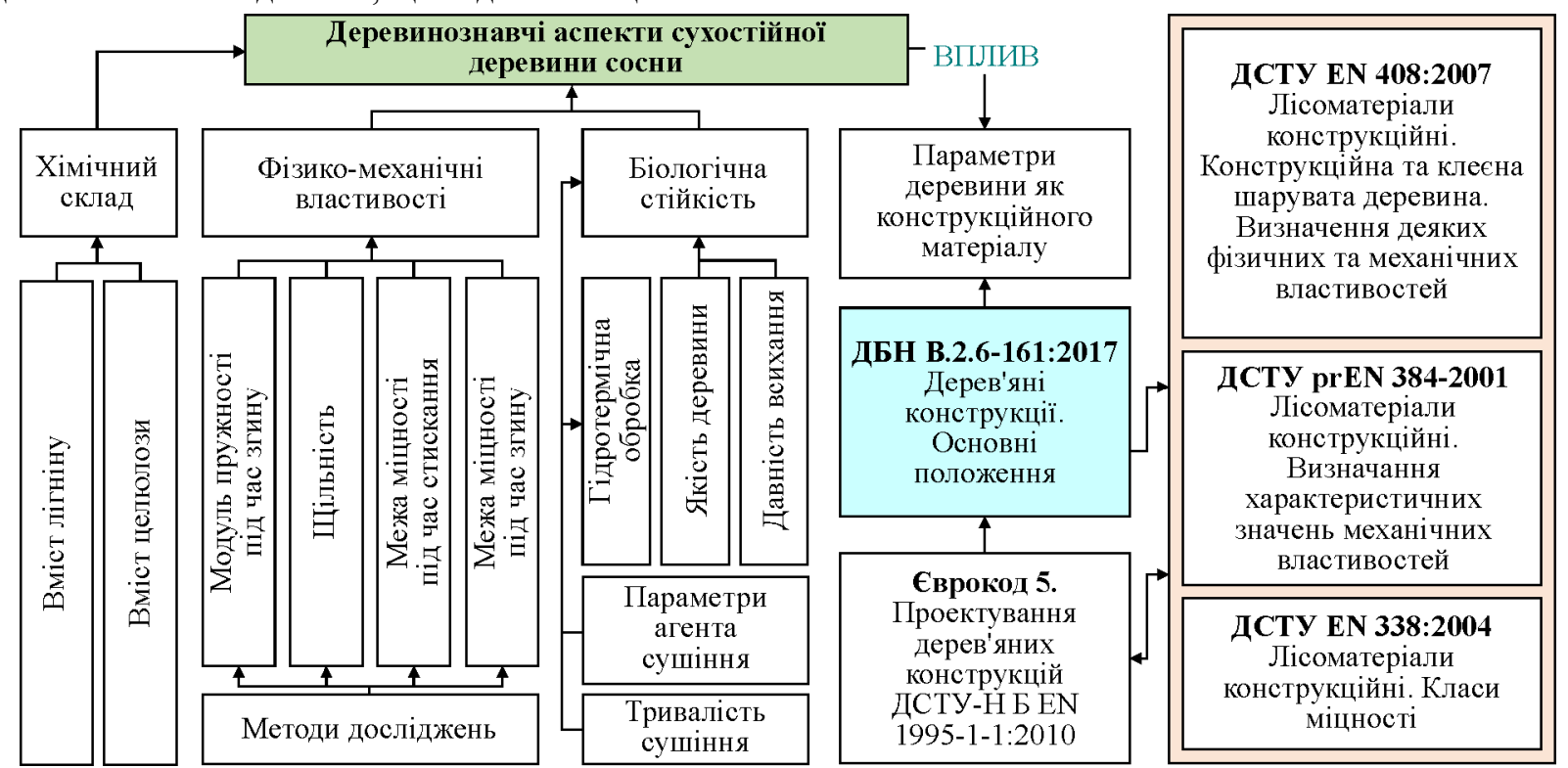

Рисунок. Блок-схема моделі досліджень деревинознавчих аспектів сухостійної деревини сосни та їх впливу на показники конструкційних лісоматеріалів

Також встановлено вплив гідротермічної оброблення деревини за різних температур на життєздатність гіфів грибів. Для того відбирали проби непошкодженої всиханням та сухостійної деревини сосни давністю всихання до 1-го, 2-х та 3-х років, які піддавали обробці різними температурами. Контрольну групу зразків не обробляли. Сушіння проводили за стерильних умов, після чого проби розміщували в чашках Петрі на живильному середовищі Сабуро (ГОСТ 9.048-89). Чашки герметизували та витримували протягом 28 днів за температури $29^{ \pm 2} \circ \mathrm{C}$ і відносної вологості повітря не більше $90 \%$.

Другий етап досліджень охоплював визначення та розрахунок показників міцності та жорсткості відповідно до методик міждержавних стандартів (ГОСТ 16483.3-84, 16483.9-73, 16483.10-73) та чинних національних, гармонізованих із європейськими (ДСТУ ЕN 408:2007, 384:2001, 338:2004) за допомогою універсальної розривної машини Р-5. Отримані результати порівнювали з відповідними значеннями нормативних показників, зазначених у ДСТУ ЕN 338:2004 "Лісоматеріали конструкційні. Класи міцності", за якими у ДБН В.2.6161:2017 "Конструкції будинків і споруд. Дерев'яні конструкції" регламентовано визначення характеристичних значень показників міцності, жорсткості та щільності. Визначення щільності деревини проводили ваговим методом (ISO 13061-2:2014).

Результати дослідження та їх обговорення. Важливою деревинознавчою характеристикою для розуміння сухостійної деревини як матеріалу $є$ водопоглинання. Зважаючи на те, що такій деревині притаманні мікологічні ураження, які зазвичай характеризуються зміною кольору деревини, спричиненою діяльністю деревозабарвлювальних грибів, цей показник має практичне значення у разі просочення пиломатеріалів зі сухостійних дерев антисептичними та вогнезахисними засобами, за умов їх використання в конструкціях та дета- лях будівельного призначення. Результати досліджень показали, що межа водопоглинання сухостійної деревини сосни давністю усихання до 1-го року становить близько $154^{ \pm 15,5} \%$, до 2 -х років - $175^{ \pm 23,9} \%$, до 3 -х років $-191^{ \pm 5,14} \%$, деревини з неослабленим всиханням деревостанів - $170^{ \pm 5,31} \%$.

Нижче значення межі водопоглинання сухостійної деревини до одного року всихання, порівняно з неураженою деревиною, пояснюємо тим, що з розвитком міцелій деревозабарвлювальних грибів просувається по серцевинних променях, проникаючи у клітини (Реrelygin, 1969), що спричиняє процес відмирання деревини i, як наслідок, закупорення трахеїд смолянистими сполуками. Подальше зростання показника водопоглинання зі збільшенням давності всихання деревини пов'язане $з$ розкладом легкорозчинних поживних речовин у порожнинах клітин та утворенням перфорації в мембранах облямованих пор внаслідок діяльності деревинозабарвлювальних грибів.

У межах виконання досліджень із впливу температури термічної оброблення на життєздатність деревозабарвлювальних грибів виявлено, що для запобігання подальшому розвитку та поширенню грибних уражень в сухостійній деревині сосни звичайної рекомендованою температурою іiї оброблення може бути $120^{\circ} \mathrm{C}$ та вище (табл. 1).

Табл. 1. Наявність життсдіяльних процесів деревозабарвлювальних грибів у сухостійній деревині сосни звичайної після термічного оброблення

\begin{tabular}{|c|c|c|c|c|}
\hline \multirow{2}{*}{$\begin{array}{c}\text { Давність всихання } \\
\text { деревостанів }\end{array}$} & \multicolumn{4}{|c|}{ Температуре оброблення $t,{ }^{\circ} \mathrm{C}$} \\
\hline & $\begin{array}{l}\text { необроб- } \\
\text { лені }\end{array}$ & 77 & 100 & 120 \\
\hline 1 рік & + & + & + & \\
\hline 2 роки & + & + & + & \\
\hline 3 роки & + & + & + & + \\
\hline $\begin{array}{c}\text { Деревина без ознак } \\
\text { всихання }\end{array}$ & + & + & & \\
\hline
\end{tabular}


Встановлено, що після термічного оброблення за температури $120^{\circ} \mathrm{C}$ в усіх дослідних зразках із деревини, давністю усихання до 1-го року, життєздатних процесів грибів не було виявлено. У $13 \%$ та $100 \%$ зразків сухостійної деревини сосни терміном усихання до 2-х та 3-х років відповідно було виявлено життєздатні гіфи та спори грибів, тому для них рекомендованою $є$ температуре оброблення значно вища за $120^{\circ} \mathrm{C}$.

Для визначення можливості використання ураженої деревини сосни як конструкційної виконано дослідження 3 визначення основних характеристичних значень зразків сухостійної деревини 1-го року всихання.

Варто зауважити, що конструкційні пиломатеріали повинні відповідати нормативам, які застосовують під час проектування будівельних конструкцій з цільної та клеєної деревини і які регламентують державні будівельні норми (ДБН В.2.6-161:2017). Дерев'яні конструкції всіх типів повинні задовольняти такі вимоги: механічну міцність, стійкість, довговічність та експлуатаційну придатність згідно з цим документом. Тому виникає потреба оцінки експлуатаційних властивостей конструкційних пиломатеріалів у межах однієї породи з обов'язковим визначенням реальної несучої здатності, яку не можливо встановити візуально, тільки на основі кількості та якості вад деревини (Tambi, 2015).

Однак наявні на сьогодні методи визначення фізикомеханічних властивостей деревини, які й визначають експлуатаційну придатність, регламентовані великою кількістю нормативних документів як національного (ДСТУ) значення, так і міждержавного (ГОСТ), європейського (EN) та міжнародного (ISO). Тому серед великої кількості показників фізико-механічних властивостей деревини й пиломатеріалів для подальших досліджень було виділено найбільш значущі для конструкційного використання деревини. До них належать такі показники, як: модуль пружності за статичного згину, межа міцності за статичного згину та стискання, а також щільність, яка здебільшого визначає якісну характеристику деревини.

3 огляду на перехід України до технічних правил $\mathrm{i}$ стандартів СС (постанова Кабінету Міністрів України № 695 від 09.12.2014 р., наказ ДП "УкрНДНЦ" № 184 від 14.12.2015р.), експериментальні дослідження було виконано на основі методів, передбачених базовими міждержавними та національними, гармонізованими 3 європейськими (повна ідентичність), нормативними документами (табл. 2).

Такий вибір обгрунтовано тим, що на сьогодні для аналізу й використання на практиці існує значний статистичний матеріал щодо показників фізико-механічних властивостей деревини різних порід, отриманий на основі досліджень на малих чистих зразках за міждержавними (ГОСТ) стандартами, який зведено у вигляді таблиць стандартизованих довідкових даних ГСССД 69-84, що містять 16 показників для 167 порід деревини.

За результатами виконаних досліджень, наведених у табл. 2, встановлено, що сухостійна деревина сосни, давністю всихання до 1-го року, повністю задовольняє вимоги дерев'яних конструкцій, встановлених у ДБН В.2.6-161:2017 і можна використати як конструкційний матеріал.
Табл. 2. Характеристичні значення основних фізико-механічних показників сухостійної та здорової деревини сосни звичайної

\begin{tabular}{|c|c|c|c|c|c|}
\hline \multirow[b]{2}{*}{$\begin{array}{l}\text { Назва по- } \\
\text { казника }\end{array}$} & \multicolumn{3}{|c|}{ Методика за ГОСТ } & \multicolumn{2}{|c|}{$\begin{array}{c}\text { Методика за } \\
\text { ДСТУ EN } 408\end{array}$} \\
\hline & $\begin{array}{l}\text { дос- } \\
\text { лідні } \\
\text { дані }\end{array}$ & $\begin{array}{l}\text { довіднико- } \\
\text { ві дані } \\
\text { (Bokshcha- } \\
\text { nin, 1987) }\end{array}$ & $\begin{array}{c}\text { ДБН } \\
\text { В.2.6- } \\
161: 2010\end{array}$ & $\begin{array}{c}\text { ДБН } \\
\text { В.2.6- } \\
161: 2017\end{array}$ & $\begin{array}{l}\text { дос- } \\
\text { лідні } \\
\text { дані }\end{array}$ \\
\hline $\begin{array}{c}\text { Межа міц- } \\
\text { ності за ста- } \\
\text { тичного } \\
\text { згину, МПа }\end{array}$ & $\frac{67,1}{76}$ & 88,3 & 80 & $14-50$ & $\frac{50,3}{50,4}$ \\
\hline $\begin{array}{c}\text { Модуль } \\
\text { пружності } \\
\text { за статично- } \\
\text { го згину, } \\
\text { ГПа }\end{array}$ & $\frac{17,4}{19,3}$ & 16,8 & 10 & $7-16$ & $\frac{9,8}{9,9}$ \\
\hline $\begin{array}{c}\text { Межа міц- } \\
\text { ності за } \\
\text { стискання } \\
\text { вздовж во- } \\
\text { локон, МПа }\end{array}$ & $\frac{42,1}{43,9}$ & 50,5 & 44 & $16-29$ & $\frac{53,6}{57,8}$ \\
\hline $\begin{array}{c}\text { Середня } \\
\text { щільність, } \\
\mathrm{\kappa г}^{3} \mathbf{M}^{3}\end{array}$ & $\frac{484}{476}$ & 525 & - & $350-550$ & $\frac{475}{523}$ \\
\hline
\end{tabular}

Примітка 1. У чисельнику значення для сухостійної деревини давністю усихання до 1-го року, в знаменнику для здорової деревини (контрольні зразки)

Висновки. Дослідження з визначення межі водопоглинання підтвердили наявність тенденції до підвищення водопоглинальної здатності від давності всихання сухостійної деревини, що зумовлено діяльністю деревинозабарвлювальних грибів.

Визначено, що сухостійну деревину сосни звичайної давністю усихання до 1-го року, оброблену за температури $t=120{ }^{\circ} \mathrm{C}$, можна використовувати як конструкційний матеріал. Характеристичні значення міцності, жорсткості та щільності такої деревини знижуються в межах 5 \%, порівняно зі здоровою деревиною.

Значення фізико-механічних показників деревини сосни звичайної, отримані згідно з методиками ГОСТ та ДСТУ ЕN, значно відрізняються (до 64 \%). Це пояснюємо принциповими відмінностями методик проведення досліджень, що не дає змогу безпосередньо порівняти дані без введення перевідного коефіцієнта.

\section{Перелік використаних джерел}

Beliaev, I. N. (2011). Povyshenie kachestvennogo vykhoda lesomaterialov $\mathrm{v}$ zone usykhaiushchikh elovykh drevostoev Arkhangelskoi oblasti. [Improvement of the qualitative yield of timber in the zone of drying fir tree stands in the Arkhangelsk region]. Extended abstract of candidate's thesis. Arkhangelsk. [In Russian].

Bokshchanin, Iu. R., Kviatkovskaia, A. P., Lashmanov, V. I., Sergeev, B. V., \& Khodak, V. M. (1987). Spravochnik mastera derevoobrabotki. [Handbook of the master of wood processing]. [In Russian].

Larinina, Iu. A., Blintcov, A. I., Khvasko, A. V., \& Ermokhin, M. V. (2014). Izmenenie mekhanicheskikh svoistv drevesiny usykhaiushchikh i sukhostoinykh derevev eli evropeiskoi. [The change in the mechanical properties of the wood of the shrinking and dead trees of European spruce]. Proceedings of BSTU, 1, 221224. [In Russian].

Perelyigin, L. M. (1969). Drevesinovedenie. [Wood science]. Moscow: Lesnaia promyshlennost. [In Russian].

Tambi, A. A. (2015). Nauchnye osnovy sortoobrazovaniia pilomaterialov. [Scientific basics of grade-formation of lumber]. Doctor's thesis. Saint Petersburg. [In Russian]. 


\section{ДРЕВЕСИНОВЕДЧЕСКИЕ АСПЕКТЫ СУХОСТОЙНОЙ ДРЕВЕСИНЫ СОСНЫ ОБЫКНОВЕННОЙ}

Исследован показатель водопоглощения сухостойной древесины сосны давностью усыхания от одного до трех лет и древесины без признаков усыхания из Киевской и Житомирской областей Украины, зона Лесостепи. Подтверждено наличие тенденции к повышению водопоглощающей способности от давности усыхания сухостойной древесины. Изложены результаты экспериментальных исследований по влиянию температуры обработки сухостойной древесины сосны обыкновенной (Pinus sylvestris L.) различной давности усыхания с признаками микологических поражений на жизнеспособность гифов грибов. Проанализированы существующие методы по определению физико-механических свойств древесины, изложенные в действующих национальных, гармонизированных с европейскими, и межгосударственных нормативных документах. Установлены показатели плотности, предела прочности и модуля упругости при статическом изгибе, предела прочности при сжатии вдоль волокон для пиломатериалов из сухостойной древесины сосны обыкновенной, давностью усыхания до одного года по сравнению с древесиной без признаков усыхания. Определено, что сухостойная древесина сосны, давностью усыхания до одного года, полностью удовлетворяет требованиям к деревянным конструкциям, установленным в ДБН В.2.6161:2017, и может быть использована в качестве конструкционного материала. Предложено применение метода эвристического моделирования для изучения влияния древесиноведческих аспектов сухостойной древесины сосны обыкновенной на показатели конструкционных лесоматериалов с целью прогнозирования возможности использования такой древесины в строительных конструкциях.

Ключевые слова: деревоокрашивающие грибы; термическая обработка; физико-механические свойства; конструкционные лесоматериалы.

S. V. Novytskyi

National University of Life and Environmental Sciences of Ukraine, Kiev, Ukraine

\section{WOOD TECHNOLOGY ASPECTS OF SCOTCH PINE DEADWOOD}

Today, as a result of climatic changes, pathological processes in coniferous tree stands have intensified, which led to their drying out. This was the reason for the growth in timber harvesting, the volume of so-called "deadwood", the main feature of which is the wood-staining fungi lesions. Due to the presence of biological lesions, the use of deadwood as a fuel raw material has developed. However, current research suggests that the proportion of deadwood, after sorting, can be used as raw material for the production of structural elements of construction purposes. Therefore, the study of woodworking aspects of Scots pine (Pinus sylvestris L.) deadwood and their influence on the indicators of structural timber will find ways of effective and rational use of such wood in industry. The index of water absorption of pine deadwood with limitation of drying from one to three years and wood without signs of drying from Kiev and Zhytomyr Regions of Ukraine, the Forest-steppe zone is studied. The authors have confirmed the tendencies the water-absorbing capacity from the limitation of drying of deadwood to increase. The article is devoted to the results of experimental research of the influence of the temperature of treatment of Scots pine deadwood different limitation of drying with the signs of mycological lesions on the viability of hyphae of fungi. The existent methods of determining the physical and mechanical properties of wood stated in the existing national, harmonized with European, and interstate regulatory documents is analysed. The parameters of density, tensile strength and modulus of elasticity in bending, tension strength parallel to the grain for sawn deadwood Scots pine timber with limitation of drying to one year in comparison with wood without signs of drying. It is determined that the deadwood of Scots pine, the limitation of drying up to 1 year, fully meets the requirements for wooden structures installed in DBN B.2.6-161:2017, and can be used as a structural material. The application of the heuristic modeling method for the study of the influence of woodworking aspects of deadwood of Scots pine on the parameters of construction timber in order to predict the possibility of using such wood in building structures is proposed.

Keywords: wood-staining fungi; heat treatment; physical and mechanical properties; constructional timber. 